\title{
How do Primary Health Care Workers Perceive and Practice Post Exposure Prophylaxis for HIV in Enugu State?
}

\author{
Uzochukwu BSC ${ }^{1-3^{*}}$, Sibeudu $\mathrm{FT}^{4}$, Ughasoro $\mathrm{MD}^{3,5}$, Okwuosa $\mathrm{C}^{3}$ and Onwujekwe $\mathrm{OE}^{2,3,6}$ \\ ${ }^{1}$ Department of Community Medicine, University of Nigeria, Enugu Campus, Enugu, Nigeria \\ ${ }^{2}$ Department of Health Administration and Management, University of Nigeria Enugu Campus, Enugu, Nigeria \\ ${ }^{3}$ Health Policy Research Group, University of Nigeria Teaching Hospital, Enugu, Nigeria \\ ${ }^{4}$ Department of Nursing Science, Nnamdi Azikiwe University, Nnewi, Nigeria \\ ${ }^{5}$ Department of Paediatrics, University of Nigeria Enugu Campus, Enugu, Nigeria \\ ${ }^{6}$ Department of Pharmacology and Therapeutics, University of Nigeria Enugu Campus, Enugu, Nigeria
}

"Corresponding author: Uzochukwu Maduka D, Health Admin and Management, FWACP, University of Nigeria, Enugu Campus, Enugu, Nigeria, Tel: 2348060388863; E-mail: kakatitis@yahoo.co.uk

Received date: August 02, 2014; Accepted date: November 19, 2014; Published date: November 25, 2014

Copyright: $\odot 2014$ Uzochukwu, et al. This is an open-access article distributed under the terms of the Creative Commons Attribution License, which permits unrestricted use, distribution, and reproduction in any medium, provided the original author and source are credited.

\begin{abstract}
Background: Healthcare providers are in constant risk of exposure to Human Immunodeficiency Virus (HIV) during their routine practice. This makes it paramount to evaluate their knowledge, attitude and practice of PostExposure Prophylaxis (PEP). Since this will determine their likely line of action if exposed to HIV. Therefore, this study aimed to determine their level of knowledge, altitude and practice of PEP among Primary health care workers in Enugu State.
\end{abstract}

Method: The study was a descriptive cross sectional study conducted in Enugu state, South East Nigeria. Data were collected from 129 health workers in 10 primary health centers using questionnaire adopted from the US guideline for the management of occupational exposure. Data was analysed using SPSS

Result: About $86 \%(111 / 129)$ had knowledge of PEP, 92.2\% (119/129) agreed that PEP reduces the risk of occupational HIV and 29\% (38/129) treated themselves with PEP on exposure aggressively, while $71 \%(91 / 129)$ were not serious with PE treatment. On their practice of PEP, $17.8 \%(23 / 129)$ were frequent, $26.4 \%(34 / 129)$ practice is sometimes, $27.9 \%$ (36/129) were regular and $27.9 \%$ (36/129) do not practice PEP.

Conclusion: The gap between the impressive knowledge or attitude on PEP by the healthcare workers and their poor practices is unacceptable. A study to determine factors that contribute to the poor practices can provide solution on how to improve on their practice and therefore, reduces the risk of getting infected when exposed to HIV.

Keywords: Human Immune Deficiency Virus (HIV); Post Exposure Prophylaxis (PEP); Health workers; Knowledge; Attitude and practice

\section{Introduction}

Human Immunodeficiency Virus (HIV) is a disease of public health importance, especially in sub-Sahara Africa countries including Nigeria [1,2]. The endemicity of the disease in this region has increased the risk of contracting HIV especially by healthcare providers, thus one of the main occupational hazard faced by healthcare providers practicing in this locality. The coming in contact with HIV infected blood products and/or body fluids remain the major occupational exposure to this disease [3-5].

A healthcare provider who is any person working in any health facilities is at the risk of coming in contact with contaminated medical materials and infective body products. The risk of HIV infection increases if a percutaneous injury; needle stick or medical sharp injuries, or contamination of break in skin or mucus membrane has occurred. The risks differ with different exposures [6,7]. Although there are multiple factors that influence the risk of post-exposure HIV transmission [8], but for a percutaneous or mucus membrane exposure, the probable risks are $0.3 \%$ [9] and $0.09 \%$ [10] respectively.

The prevention of exposure has remained the most important strategy for a reduction in occupational HIV infection, essentially though observation of universal precautions [11] and taking necessary precautions to prevent injuries caused by infected medical sharp instruments and devices. However, adherence to universal precautions has been noted to be generally poor especially in developing countries $[12,13]$. Therefore, occupational exposure still occur and when it does occur, immediate management of the exposure and institution of postexposure prophylaxis where indicated [14].

The PEP strategy has different components: source patient HIV testing, correct combination of 2 or 3 anti-retroviral agents and commencing treatment within 72 hours of exposure, appropriate timing and duration of treatment, monitoring and management of drug toxicity, follow-up and post-exposure HIV testing [15]. In view of the above stated, it is paramount that healthcare providers are knowledgeable on PEP strategies and are able to act promptly and effectively when occupation exposure occurs. An action that has been noted to decrease the risk of HIV infection by approximately $80 \%$ [16]. 
However, it will be an unacceptable assumption to conclude that healthcare providers practicing in Nigeria, as well as other developing countries, are knowledgeable on PEP strategies. As at the time of this study, our literature review was could not identify any study that evaluated the knowledge, attitude and practice of healthcare providers on PEP strategies. This revealed dearth in data, was what our study aimed to provide. The outcome of this study will identify any deficit in knowledge and practice which health programme managers will find relevant in design of any intervention aimed to improve PEP activities in health facilities.

\section{Methods}

\section{Study area}

The study was carried out in Enugu metropolitan in Enugu State, southeast Nigeria. It is made up of 3 local government Areas namely Enugu North, Enugu South and Enugu East L.G.A accounting for 22\% of Enugu state population. Enugu metropolitan has 23 primary health care centers of which 10 are selected randomly for the study.

\section{Design}

The study was a descriptive cross sectional study carried out from January 2009 to December 2009 on primary health care workers.

\section{Data collection}

Data were collected with interviewer administered questionnaire from 129 categories of health workers from the 10 primary health centers who consented to the interview. The questionnaire was developed based on the major components of the updated US public health service guidelines for the management of occupational exposure to HIV and recommendation for post-exposure prophylaxis. The component were: definition of post-exposure prophylaxis, antiretroviral agent (ARA) for PEP, treatment and drug interaction of ARA, selection of HIV PEP regimen, management of exposure and time and duration of PEP, post-exposure testing. Based on these components, their knowledge, attitude and practice of post exposure prophylaxis for HIV among primary Health care workers were collected.

\section{Data Analysis}

Data entry and analysis were done using statistical package for social sciences (SPSS) variables from the data, variables like, respondents exposure to patients body fund, type of body fluid, route of exposure, frequency of exposure and intervention; knowledge of post exposure prophylaxis (PEP) and how often the respondents practice (PEP) provision and accessibility of PEP the primary health centers were analyzed.

\section{Ethical consideration}

Ethical approval was obtained from Ethics and Health Research Committee of University of Nigeria Teaching Hospital, Enugu, Nigeria before this study was commenced. A written consent was obtained for each healthcare providers before participating in the study.

\section{Result}

Out of the 129 healthcare providers surveyed, 86.8\% (112/129) were female and majority (51.9\%) of the respondents were within the age range of 31-45 years as shown in Table 1 . Majority $(85.3 \%, 110 / 129)$ were nurses and higher percentage $(44.2 \%$; $57 / 129)$ had practiced as healthcare provider for 5 years or less. Majority 91.4 (105/129) practiced in a health care facility located in urban areas.

\begin{tabular}{|c|c|c|}
\hline Variables & $n=129$ & $\%$ \\
\hline \multicolumn{3}{|l|}{ Gender } \\
\hline Male & 112 & 86.8 \\
\hline Female & 17 & 13.2 \\
\hline \multicolumn{3}{|c|}{ Age (years) } \\
\hline $16-30$ & 38 & 29.4 \\
\hline $31-45$ & 67 & 51.9 \\
\hline $46-60$ & 24 & 17.7 \\
\hline \multicolumn{3}{|l|}{ Cadre } \\
\hline Nurses & 110 & 85.3 \\
\hline Doctor & 7 & 5.4 \\
\hline Others & 12 & 9.3 \\
\hline \multicolumn{3}{|c|}{ Location of work place } \\
\hline Urban & 105 & 91.4 \\
\hline Rural & 24 & 18.6 \\
\hline \multicolumn{3}{|c|}{ Period practiced (years) } \\
\hline $1-5$ & 57 & 44.2 \\
\hline $6-10$ & 28 & 21.7 \\
\hline $11-15$ & 12 & 9.3 \\
\hline$\geq 16$ & 32 & 24.8 \\
\hline
\end{tabular}

Table 1: Demographic characteristics of the respondents.

All (100\%) of the healthcare providers studied have been exposed to a patient's body fluid. Majority (93\%) were exposed to blood product, and needle stick injury was the commonest $(36.4 \%)$ as shown in Table 2. Frequent exposure occurred in $6.2 \%$ (8/129) of the respondents, while 54.3\% (70/129) had a rare exposure. The commonest intervention instituted was washing with soap and plenty of water (42.6\%) and washing with antiseptics (34.9\%).

\begin{tabular}{|l|l|l|}
\hline Variables & N=129 & $\%$ \\
\hline Route of exposure & 47 & 36.4 \\
\hline Needle stick & 38 & 29.5 \\
\hline Intact Skin & 20 & 15.5 \\
\hline Through an open wound & 19 & 14.7 \\
\hline Splash to eye into nose mouth & & \\
\hline
\end{tabular}


Citation: Uzochukwu BSC, Sibeudu FT, Ughasoro MD, Okwuosa C, Onwujekwe OE (2014) How do Primary Health Care Workers Perceive and Practice Post Exposure Prophylaxis for HIV in Enugu State?. J AIDS Clin Res 5: 381. doi:10.4172/2155-6113.1000381

Page 3 of 5

\begin{tabular}{|l|l|l|}
\hline Puncture of skin by wide bore needle & 3 & 2.3 \\
\hline Injury during surgical procedure & 2 & 1.6 \\
\hline Frequency of such exposure & 8 & 6.2 \\
\hline Very often & 51 & 39.5 \\
\hline Often & 70 & 54.3 \\
\hline Rerely & \multicolumn{2}{|l|}{} \\
\hline Interventions given in such occurrences & 55 & 42.6 \\
\hline Wash with soap and planting of water & 45 & 34.9 \\
\hline Wash with antiseptics & 22 & 17.1 \\
\hline Allowed blood to freely flow from site of injury & 3 & 2.3 \\
\hline Take drug & 4 & 3.1 \\
\hline Go for medical counseling & \multicolumn{2}{|l|}{} \\
\hline
\end{tabular}

Table 2: Exposure to patient's body fluid, type of body fluid, route of exposure, frequency of exposure and intervention.

From the figure below 128 (99.2\%) of respondent were aware of contracting blood borne pathogen on being exposed while $0.8 \%$ do not know.

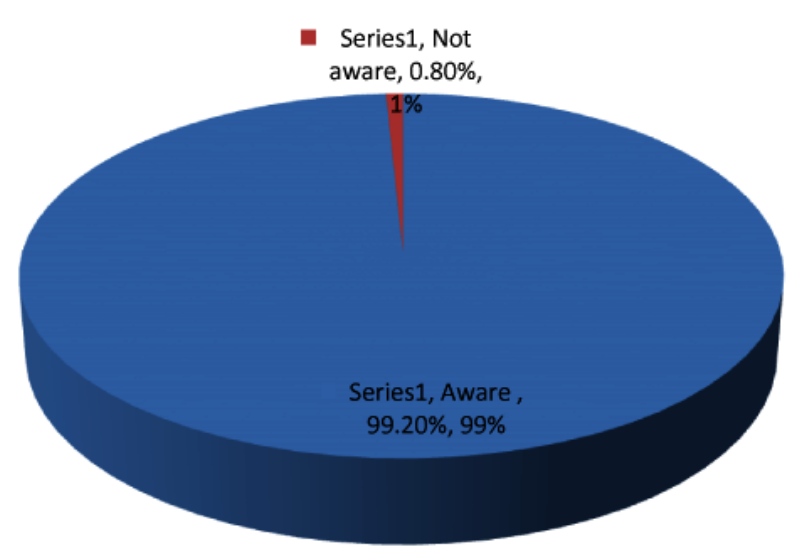

Figure 1: Awareness of contracting blood borne pathogen on exposure.

From the Table 3, 86\% of respondent know about PEP while $18 \%$ do not know about PEP, $23 \%$ practice it frequency $34 \%$ practice it some time, $36 \%$ rarely practice PEP and $36 \%$ does not practice PEP. According to the respondents $22.5 \%$ of other health care workers practice PEP, $24.8 \%$ practice it some times, $24 \%$ rarely practice it and $28.7 \%$ do not practice PEP.

From Table 4, 4.7\% of respondents said that PEP is provided in their place of work, $93 \%$ of respondent said that it is not provided and $1.6 \%$ do not know whether it is provide. $2.3 \%$ said that PEP is very accessible in their place of work. $92.2 \%$ of respondent agree that PEP reduces the risk of occupational acquired HIV and HBV, 7\% do not agree and $0.8 \%$ do not know whether PEP for HIV and HBV reduces the risk occupational infection.

\begin{tabular}{|l|l|l|}
\hline Variables & N=129 & $\%$ \\
\hline Knowledge & 111 & 86.0 \\
\hline Yes & 18 & 14.0 \\
\hline No & \multicolumn{2}{l|}{} \\
\hline How often the respondent practices PEP & 23 & 17.8 \\
\hline Frequently & 34 & 26.4 \\
\hline Some time & 34 & 27.9 \\
\hline Rarely & 36 & 27.9 \\
\hline Does not & 36 & \\
\hline How often other health workers practices PEP & \multicolumn{2}{|l|}{} \\
\hline Frequently & 29 & 22.5 \\
\hline Some time & 32 & 24.8 \\
\hline Rarely & 31 & 24.0 \\
\hline Does not & 31 & 28.7 \\
\hline
\end{tabular}

Table 3: Knowledge of post exposure prophylaxis (PEP) and how often the respondents or any other primary health care worker practice PEP.

\begin{tabular}{|c|c|c|}
\hline Variables & $N=129$ & $\%$ \\
\hline \multicolumn{3}{|c|}{ Provision of PEP services } \\
\hline Yes & 6 & 4.7 \\
\hline No & 121 & 93.8 \\
\hline Don't know & 2 & 1.6 \\
\hline \multicolumn{3}{|c|}{ Accessibility of PEP services } \\
\hline Very accessible & 3 & 2.3 \\
\hline Accessible & 3 & 2.3 \\
\hline Not accessible & 123 & 95.3 \\
\hline \multicolumn{3}{|c|}{ Whether PEP reduces risk of infection } \\
\hline Yes & 119 & 92.2 \\
\hline No & 9 & 7.0 \\
\hline Don't know & 1 & 0.8 \\
\hline
\end{tabular}

Table 4: Provision and accessibility of pep in health center.

From the Table 5, 3.1\% of respondents said that zidovudin is provided, $0.8 \%$ said that lamivudin is provided $95.3 \%$ said that no HIV drug is provided and $0.8 \%$ said that other antiviral drugs are provided. 
94.5\% of respondents said that no hepatitis B Post exposure prophylaxis drug is provided, $3.9 \%$ said that hepatitis $\mathrm{B}$ vaccine is provided and $1.6 \%$ said that hepatitis B immunoglobulin is provided.

From the Table $6,20.1 \%$ of respondents believe that occupational acquired HIV and $\mathrm{HBV}$ can be reduced through careful and protective practices by health workers, $7.8 \%$ said that it is through enlightenment campaign, creation of awareness and education of health workers, $58.1 \%$ suggested government intervention through provision of steady PEP drugs and facilities, $4.7 \%$ also suggested avoidance of careless sexual practice, risk behavior and unnecessary attachment to patients and exposed persons.

\begin{tabular}{|l|l|l|}
\hline HIV PEP drugs & $\mathbf{N = 1 2 9}$ & \% \\
\hline Zidovudin & 4 & 3.1 \\
\hline Lamivudin & 1 & 0.8 \\
\hline Others & 1 & 0.8 \\
\hline Non & 123 & 95.3 \\
\hline
\end{tabular}

Table 5: Drug for post exposure prophylaxis.

\begin{tabular}{|l|l|l|}
\hline $\begin{array}{l}\text { Options on how to reduce occupational HIV and } \\
\text { HBV }\end{array}$ & $\mathbf{N}=\mathbf{1 2 9}$ & $\%$ \\
\hline Careful and protective practices by health workers & 26 & 20.1 \\
\hline $\begin{array}{l}\text { Enlightenment campaign creation of awareness and } \\
\text { education of health workers }\end{array}$ & 10 & 7.8 \\
\hline $\begin{array}{l}\text { Government intervention through provision of steady } \\
\text { PEP dugs and facilities etc }\end{array}$ & 75 & 58.1 \\
\hline $\begin{array}{l}\text { Avoid careless sexual practices risk behavior and } \\
\text { unnecessary attachment to patients }\end{array}$ & 6 & 4.7 \\
\hline $\begin{array}{l}\text { Proper treatment and careful follow up of patients and } \\
\text { exposed persons }\end{array}$ & 12 & 9.8 \\
\hline
\end{tabular}

Table 6: Suggestion on how health work could reduce occupational acquired HIV and HBV.

\section{Discussion}

From our result, $99.2 \%$ of the respondents were aware of contacting blood borne pathogens when exposed to patient's fluid and $86 \%$ knew about post-exposure prophylaxis. The high level of awareness of contacting pathogens from patient fluid may contribute to high level of knowledge of post exposure prophylaxis for HIV in the study area. The proportion of nurses (56.6\%) and doctors (27.9\%) in this study may have contributed in the level of awareness because studies revealed that nurses adhere to universal precautions more than doctors [17-19] and majority of doctors were not aware of CDC guideline on universal precaution against blood borne pathogen [19]. This is consistent with the findings in Uganda that showed that 95\% of health workers were aware of post exposure prophylaxis with nurses having highest percentage [20].

In our study, all the respondents have been exposed to patient's body fluid but the routes of exposure differ: open wound (15.5\%); intact skin $(29.5 \%)$; splash to the eye $(14.7 \%)$; needle stick $(36.4 \%)$; puncture of skin by wide bore needle (2.3\%); injury during surgical procedure $(1.6 \%)$. Risk of contracting infection is dependent on the integrity of the exposed site; the type and volume of body fluid and viral load. Needle stick has the greatest percentage showing the importance of needle safety in patients care to reduce approximately 1 million health workers that suffer needle stick injuries each year. The percentages of injury during surgical procedure can be attributed to the type and number of surgical procedures that can be done in the primary health care centers. This was evidenced in the study which was done in a hospital setting and found out that $82.9 \%$ of staff were exposed to patient's fluid through percutaneous injury. There is also greater percentage of doctors in the hospital setting who will be exposed to percutaneous injuries while carrying out their duties [20]. In our study, $70(54.3 \%)$ were rarely exposed 51 (39.5\%) were exposed often and $8(6.2 \%)$ were exposed very often. This is contrary to other findings on post exposure prophylaxis after occupational and nonoccupational exposure of HIV where $21 \%$ were exposed very often [21] however non occupational exposure may contribute to the frequency of the exposure.

In our study, after exposure to HIV, approximately $30 \%$ will ensure they take necessary treatment, which is not good enough comparing the level of exposure health workers in developing country's experience. Moreover, the attitude of health workers on being exposed influences the outcome of exposure. It was noted that post exposure prophylaxis should be commenced preferably one hour after exposure but up to 2 weeks after exposure one may still commence the treatment and still benefit. However, some authors linked it to absence of written standing orders procedure regarding to needle stick in hospital, stigmatization which is still common in developing countries and no availability of PEP drugs. This is consistent with some studies were only $28 \%$ had sought advice for PEP after exposure [14] and $7 \%$ in another study [22].

This study also revealed that approximately $94 \%$ of the respondents agreed that there is no provision or access to PEP in the health centers. In this study, we tried to find out why the primary health care workers have varying attitude on being exposed to body fluid, we found out that $95.3 \%$ primary health care workers do not have prophylaxis provide in their health centers. The unavailability of this all important prophylaxis may be the reason why majority of the health workers interviewed do not seek for prophylaxis after exposure. The inaccessibility of HIV prophylaxis could explain the poor attitude to post exposure prophylaxis for HIV.

This study, found out that majority of the respondents (92.2\%) agreed that PEP reduces the risk of occupational acquired HIV but only $12.8 \%$ frequently practiced it when they are exposed. This could be the implication of unavailability of PEP drug (95.3\%); poor accessibility to post prophylaxis drugs (95.3\%) experience by the health workers and some factors like stigmatization There is in line with findings in Malugo hospital in Uganda where 61\% believed PEP can work but only $28 \%$ had ever sought advice on Post exposure prophylaxis which was linked to stigmatization, unavailability of PEP with no standard system set up to make it easy for one to go through the process [22].

\section{Conclusion}

There is overwhelming knowledge of PEP for HIV in the study area but its practice is very poor. Therefore, there is need for adequate provision of PEP drugs and materials for universal precaution; explicit guideline for PEP therapy and proper recording of information concerning PEP in the work place. 
Citation: Uzochukwu BSC, Sibeudu FT, Ughasoro MD, Okwuosa C, Onwujekwe OE (2014) How do Primary Health Care Workers Perceive and Practice Post Exposure Prophylaxis for HIV in Enugu State?. J AIDS Clin Res 5: 381. doi:10.4172/2155-6113.1000381

Page 5 of 5

\section{References}

1. Jeff A, Slind J (1998) Updated US Public Health Service, Guideline for the Management of Occupational exposure to HBV, HCB, and HIV. Centre for Disease Control and prevention 21: 115-117.

2. AIDS and HIV information from AVERT.org. HIV and AIDS in Nigeria..

3. Ann JP, Jumbo E (2005) Post exposure prophylaxis to prevent HIV infection. WHO/ILO Guideline 5: 1-40.

4. Mark Cichocki (2009) Decreasing HIV risk with post exposure prophylaxis. About.com guide.

5. Landovitz RJ, Currier JS (2009) Clinical practice. Postexposure prophylaxis for HIV infection. N Engl J Med 361: 1768-1775.

6. Centers for Disease Control and Prevention (1998) Public Health Service guidelines for the management of healthcare workers exposures to HIV and recommendations for post exposure prophylaxis. MMWR Recomm Rep 47: 1-33.

7. US. Public Health Service (2001) Updated U.S. Public Health Service Guidelines for the Management of Occupational Exposures to HBV, $\mathrm{HCV}$, and HIV and Recommendations for Postexposure Prophylaxis. MMWR Recomm Rep 50: 1-52.

8. Cardo DM, Culver DH, Ciesielski CA, Srivastava PU, Marcus R, et al. (1997) A case-control study of HIV seroconversion in health care workers after percutaneous exposure. Centers for Disease Control and Prevention Needlestick Surveillance Group. N Engl J Med 337: 1484-1490.

9. Bell DM (1997) Occupational risk of human immunodeficiency virus infection in healthcare workers: an overview. Am J Med 102: 9-15.

10. Ippolito G, Puro V, De Carli G (1993) The risk of occupational human immunodeficiency virus infection in health care workers. Italian Multicenter Study. The Italian Study Group on Occupational Risk of HIV infection. Arch Intern Med 153: 1451-1458.

11. Ooi C, Dayan L, Yee L (2004) Knowledge of post exposure prophylaxis (PEP) for HIV among general practitioners in northern Sydney. Sex Transm Infect 80: 420.

12. Centers for Diseases Control and Prevention (1994) Recommendation for the use of zidorudine to reduce prenatal transmission of human immunodeficiency virus. MMVR 43: 1-20.
13. Kermode M, Jolley D, Langkham B, Thomas MS, Crofts N (2005) Occupational exposure to blood and risk of blood borne virus infection among health care workers in rural north Indian health care settings. AM J infect control 33: 34-41.

14. Alenyo R, Fualal J, Jombere JJ (2009) Knowledge, attitude and practices of staffs towards Post-exposure prophylaxis for HIV infection at Mulago hospital in Uganda. East Cent Afri J Surg 14: 99-102.

15. Kuhar DT, Henderson DK, Struble KA, Heneine W, Thomas V, et al. (2013) Updated US public health service Guidelines for the management of occupational exposures to Human Immunodeficiency Virus and recommendations for postexposure prophylaxis. Infection control and Hospital Epidemiology 34: 875-892.

16. Gammon J, Morgan-Samuel H, Gould D (2008) A review of the evidence for suboptimal compliance of healthcare practitioners to standard/ universal infection control precautions. J Clin Nurs 17: 157-167.

17. Sadoh WE, Fawole AO, Sadoh AE, Oladimeji AO, Sotiloye OS (2006) Practice of universal precautions among healthcare workers. J Natl Med Assoc 98: 722-726.

18. Adimna ED, Ezeama C, Adimna JI, Asuzu MC (2009) Knowledge and practice of Universal precaution against blood borne pathogen among house officers and nurses in tertiary health institution in south east Nigeria. Niger J Clin pract 12: 398-402.

19. Aisien AO, Shobowale MO (2005) Health care workers' knowledge on HIV and AIDS: universal precautions and attitude towards PLWHA in Benin-City, Nigeria. Niger J Clin Pract 8: 74-82.

20. Stein AD, Makarawo TP, Ahmad MF (2003) A survey of doctors' and nurses' knowledge, attitudes and compliance with infection control guidelines in Birmingham teaching hospitals. J Hosp Infect 54: 68-73.

21. Tawfik L, Kinoti SN (2006) The impact of HIV/ AIDS on the health work force in developing countries. World health Organisation.

22. Larsen C, Lot F, Basselier B, Laporte A (2002) Surveillance of postexposure prophylaxis for non-occcupational exposure to HIV in France (July 1999- December 2001). 